ESJ Humanities

\title{
Gender Performativity and Conceptual Metaphors in the Presidential Campaign Discourse: A case study from Georgia
}

\author{
Nino Guliashvili \\ Faculty of Arts and Sciences, \\ English Philology/Anglistics, Ilia State University
}

Doi:10.19044/esj.2021.v17n36p35

Submitted: 07 October 2021

Accepted: 17 October 2021

Published: 31 October 2021
Copyright 2021 Author(s)

Under Creative Commons BY-NC-ND

4.0 OPEN ACCESS

Cite As:

Guliashvili N. (2021). Gender Performativity and Conceptual Metaphors in the Presidential Campaign Discourse: A case study from Georgia. European Scientific Journal, ESJ, 17 (36), 35. https://doi.org/10.19044/esj.2021.v17n36p35

\section{Abstract}

Gender Performativity defines politicians' verbal repertoire in accordance with the social context and expectations. Social actors construct their identities in the discourse through the work of words. Conceptual metaphors are supposed to be the cognitive models of linguistic metaphoric expressions manifested in the political discourse which tend to play a significant role in the social construction of gender. The present study focuses on the use of metaphors in two presidential candidates' (Salome Zurabishvili and Grigol Vashadze) English interviews made during 2018 presidential election campaign in Georgia. Conceptual Metaphors: Politics is Journey, Politics is Sport and Politics is War are investigated in Salome Zurabishvili's and Grigol Vashadze's political speeches. The metaphoric choices the politicians make are socially determined and later on ascribed to their gender which may not be as binary as it is traditionally perceived. In today's competitive world of politics women tend to manifest their agency through the language which is rendered masculine. Therefore, critical discourse analysis (CDA) is applied to investigate the discursive construction of gender and agency through conceptual metaphors.

Keywords: Political discourse, CDA, conceptual metaphors, gender performativity 


\section{Introduction}

Language and gender research covers a wide array of scientific questions based on certain theoretical premises, shifting the research from investigating the different communicative styles of male and female discourse participants to the most up-to-date direction of the performative model of gender. The aim of the present paper is to explore and hereby, identify how gender is performed in Georgian political discourse. For this particular purpose, I make an endeavor to scrutinize Georgian Politician's discourse elections (Grigol Vashadze and Salome Zurabishvili) in relation to the 2018 Georgian presidential election. Obviously, the number of candidates was more than mentioned above; however, there was a sole female candidate and to maintain gender balance, a male candidate has been chosen in accordance with final political rivalry.

Grigol Vashadze was appointed the chairman of the United National Movement after Mikheil Saakashvili had stepped down. Vashadze's career as a leader of the party came to an end when he left the party on the $15^{\text {th }}$ of December 2020 as a response to the political turmoil that developed between the Georgian Dream and the consolidated opposition. Prior to the chairman's position, Grigol Vashadze used to hold other high-ranking positions - Deputy to the Foreign Minister and Minister of Foreign Affairs of Georgia.

Salome Zurabishvili born in Paris into a family of Georgian immigrants held senior diplomatic positions over three decades in France as well as being the Ambassador of France to Georgia. Later on, he was appointed the Foreign Minister of Georgia. After Mikheil Saakashvili's and her ways departed, he founded the Way of Georgia political Party which she led until 2010. Following the resignation from the party's leadership, she became a member of Georgian Parliament. Ultimately, she was nominated as an independent presidential candidate supported by the Georgian Dream in 2018. Salome Zurabishvili is involved in promoting women's opportunities. On October 5, 2019 he hosted the Georgian, Belgian and French women leaders' meeting: "The role of women in our society is crucial and their contribution to our political, cultural, entrepreneurial and educational circles is key to our development" (Twitter).

Both presidential candidates have been prominent in the Georgian political arena. Therefore, it is a challenge to explore and analyze how they express their political attitudes and standpoints through linguistic lenses.

The discourse may be manifesting a varied use of conceptual metaphors. However, the difference does not come as an inherent marker of female and male speech patterns; on the contrary, it is more about the social constructivist view which considers the gendered language use as the capacity for representing oneself either as a man or a woman (Cameron, 2007). This view rejects the essentialist notions of gender which establishes a clear and 
direct connection between biological sex and gender identity; the process of socialization attributes men and women to different subcultures which define their verbal repertoire (Tannen, 1991). As opposed to this viewpoint, the social constructivist approach posits that discourse participants opt for certain language patterns in order to come across either as masculine or feminine conditioned by the cultural and social context. Before the theoretical and methodological sections of the paper, the background information of the presidential candidates in the 2018 elections is presented below.

Conceptual metaphors are supposed to be the subject of the research which represent the powerful tool for establishing cognitive comparisons as well as promoting the social actors' sense of agency. In this paper, it is argued that a female politician constructs herself in the discourse through the use of conceptual metaphors that emphasize her agency. Therefore, it is of importance to reveal how the above-mentioned agency could be socially determined. At this point, a performative model of gender takes over-women, especially in politics, have a faculty to shift their roles to serve the successful agency regardless of the features that are traditionally ascribed to either femininity or masculinity.

\section{Gender, Political Discourse and CDA}

Female Politician's agency is clearly manifested in the discourse they create, and within this discourse, they are born as subjects. Their agency to some extent is represented through the use of conceptual metaphors which may highlight the intrinsic aspect that could later serve as the basis for the instrumental agency. Therefore, Critical Discourse Analysis comes into play to uncover subtle ways in which power and ideology could be scrutinized for which the text/talk is crucial. Texts are rendered as products of linguistic actions (Wodak, 2001, p.66) which represent reality through the agency. 'Agency' per se is associated with Fairclough (2003, p.22) who defines the concept as certain faculty of people to act deliberately with the realization of certain limitations though "social agents are not 'free agents', they are socially constrained, but nor are their actions totally socially determined". As it is observed, the power which is an inseparable part of social relations and the agency of social actors is also revealed through linguistic options.

Nevertheless, there is the case of linking power with a female politician. Could a female political leader be associated with power while masculinity and power are more congruent with each other? The answer to this question could be found in the management theorist Kanter's work - Men and Women of the Corporation (1993) where she argues that female power is manifest in culturally and historically determined archetypes of female power: the 'Mother', the 'Seductress', the 'Pet' and the "Iron Maiden". The latter is 
linked with exercising power directly and hereby deemed masculine and appalling.

Baxter (2012) elaborates more on these archetypes and posits that they are not 'fixed roles'; women are able to exploit them in line with varied social contexts to achieve goals. Moreover, Koller (2004 a) explains that the discourse of "Iron Maiden" might be gendered via the use of metaphors which could masculinize female subjects.

The ability of the female politicians to adjust their roles in accordance with social context maximizing their agency is reinforced in Shaw's (2020) "Gender and Political Speech" promoting "performative model of gender" which is influenced immensely by cultural values. Precisely, the ideology of "different voice" lies at the very foundation of conception that women bring about their style of establishing consensus and balance by cooperative style of communication. In reality, women who manifest strong agency and adopt socalled "masculine" ways of communication are faced with negative appraisals, which is discriminatory in itself. The aim of CDA is to look at and scrutinize to what extent the gender of the politician is performative in terms of agency.

\section{Metaphors in Political Discourse}

Lakoff and Johnson's (1980) revolutionizing conceptual metaphor theory highlights that metaphor use is an everyday verbal activity in which an abstract thing is conceptualized by another more concrete one at cognitive level and subsequently transferred into a linguistic expression or any other semiotic mode of communication. Metaphoric transfer posits that the knowledge about a source domain, for example 'Journey', is cognitively compared to a target domain, for example, LIFE, which yields a conceptual metaphor 'Life is Journey'. Linguistically, this conceptual metaphor may take the following expression: 'I'm at crossroads.' Obviously, there is ample amount of cognitive comparisons which suppose the existence of relevant linguistic expressions, for example, conceptual metaphor 'Life is Fight for Survival' which relates to the following metaphor at the language level: 'We are attacking hardships and challenges on daily basis'. Therefore, if one person opts for 'Life is Journey' cognitive model and the other - for 'Life is Fight for Survival', they conjure up different emotions and send different messages to the people they communicate with; thus, metaphor serves an interpersonal metafunction (Halliday and Matthiessen 2004). What's more, via metaphoric expressions the speakers not only posit themselves in relation to the audience, but also create certain viewpoints, represent the world from a particular standpoint realizing an ideational function through creating 'social realities' for us (Lakoff and Johnson, 1980, p.159).

Metaphors don't suffice with only the above-mentioned functions; through the ideological function, metaphor is a way of persuading the audience, 
winning the listeners to one's way of thinking, if not manipulating. Thus, metaphor contributes to the formation of ideological meanings in discourse and gender is one of the integral components of social life where ideology is pervasive. The different notions and understandings of masculinity or femininity do ideological work reifying or challenging the identities which might be beneficial for one group, but disadvantageous for the other especially in societies with 'hegemonic masculinity' (Connell, 1995; Connell and Messerschmidt, 2005). The metaphor-based gender identity construction is set in three dimensions:

- Gendered metaphors reifying power asymmetries in defining reality which solely relies on male experiences (Koller, 2004 b; Velasco Sacristan, 2005; Wilson, 1992);

- Metaphors characterizing men and women (Hegstrom and McCarlNielsen, 2002; Hines 1999; Koller, 2004 a, Luchjenbroers , 1998);

- Metaphors that are used by female and male discourse participants.

Our study investigates the third dimension of metaphor use which is based on the premise that due to socialization men and women develop different views of the world, conceptualizing it in different ways (Kovecses, 2005, p.90) and representing relevant linguistic metaphoric expressions in their verbal repertoire. Analyzing men's /women's metaphor use would allow us to make inferences with regard to the speakers' gender identity which is construed in a social context characterized by unequal power relations between genders. As previously mentioned, the research endeavors to relate conceptual metaphor theory with the social constructivist approach. It has to be mentioned that men and women apply unalike metaphors to conceptualize the same event or phenomenon (Fiksdal, 1999) thus developing their gender identities. However, gender identity is not a fixed phenomenon as opposed to an essentialist view, rather it is a linguistic resource actualizing either femininity or masculinity depending on the social context.

\section{Pronouns and Voice}

Pronouns are closely linked with agency social actors are capable of representing in the discourse. Agency, as well as discursive power and authority, could be unraveled by the use of personal pronoun 'I', which "reflects an individualistic representation of politicians as social actors" equipping them with the sense of having "power and ownership" (Ndambuki \& Janks, 2010, p.11). The use of 'I' represents a social actor as an individual, whereas 'we' portrays the actor as a part of a collective. The choice of active over passive voice for structuring the statements is hereby connected with agency and authority. Therefore, these linguistic aspects will be investigated along with the cognitive metaphor use. 


\section{Methods}

The comparative study of Salome Zurabishvili's and Grigol Vashadze's metaphor use is based on a corpus of a total of 7521 words (see Appendix for details). All the texts under investigation represent the English Language interviews in connection with the 2018 presidential elections and are accessible on the Internet platforms (for details see Appendix). The Software tool for corpus analysis is Antconc, which is free, easy to use and convenient for investigating corpora (Anthony, 2020).

The verbal unstructured data as mentioned above come from a variety of sources published on the Internet: Deutsche Welle, Euronews, Reuters, BBC news, Radio Free Europe. The recorded material has been transcribed and analyzed by Antconc. This type of data-driven analysis of discourse is referred to as sentiment analysis also known as opinion mining (Liu, 2015), which focuses on identifying how people use natural language to construct their identities (Holmes, 1998; Holmes \& Meyerhoff, 1999) and how they might influence public opinion formation.

The first step is the identification of a keyword list for each politician's mini subcorpus. As for the Metaphor identification procedure, it was carried out by the method of Pragglejaz Group (2007) yielding a number of metaphoric expressions at the text level used by each politician. The procedure was manually conducted and later on processed by Antconc tool for identifying the concordances and frequencies for quantitative as well as qualitative text analysis. This step is necessary to identify the recurrent source domains. The MIP procedure yielded a list of 21 metaphorically used lexemes. As a next step, Antconc Tool software is applied to run the concordances for 21 metaphoric types in each subcorpus to get a more in-depth analysis of metaphorically used lexemes. Based on the concordance results, the following was calculated (Koller and Semino, 2009, p.17):

- the number and percentage of types realized for each of the source domains ('Journey' and 'War') to see how productively either politician uses the metaphor;

- the number of metaphoric tokens, that is, the individual metaphoric expressions;

- the metaphoric type-token ratio (mTTR; see Koller, 2004b) to ascertain the variety with which each metaphorically used lexeme is realised. The metaphoric type-token ratio shows how often different metaphoric expressions occur in a corpus; the lower the mTTR, the less varied is the metaphor usage in the corpus. It follows that the number and percentage of metaphoric types that are realised does not correlate with the mTTR, because the number of tokens may be disproportionately higher; 
- the metaphor density per 1000 words to determine the frequency with which the metaphoric tokens in question are used by the two politicians.

Semino and Koller (2009, p.17) posit that computer-assisted corpus analysis requires establishing its relation to linguistic features such as intertextuality, negation and certainly, co-construction of the metaphor. Metaphor usage by each politician may be influenced by topic, audience and historical background.

\section{Results and Discussion}

This section below presents the most important aspects of the politicians' discourse highlighting the keywords (Table 1) and metaphor use (Table 2).

Table 1. Keywords in Salome Zurabishvili and Grigol Vashadze

\begin{tabular}{|c|c|c|}
\hline & Salome Zurabishvili & Grigol Vashadze \\
\hline Role & President Partners & \\
\hline $\begin{array}{l}\text { Proper Names: } \\
\text { Politicians }\end{array}$ & $\begin{array}{l}\text { Ivanishvili Saakashvili } \\
\text { Putin }\end{array}$ & $\begin{array}{l}\text { Saakashvili Misha } \\
\text { Salome Zurabishvili } \\
\text { Ivanishvili }\end{array}$ \\
\hline Self-reference & $I$, we & $I$, we, my, our \\
\hline Other reference & $\begin{array}{l}\text { Aggressor Georgians } \\
\text { Emigration Opposition } \\
\text { Society Parliament } \\
\text { apparatchiks }\end{array}$ & $\begin{array}{l}\text { Everybody Nobody Citizen } \\
\text { Dictator Idiot }\end{array}$ \\
\hline $\begin{array}{l}\text { Proper Names: } \\
\text { Countries }\end{array}$ & 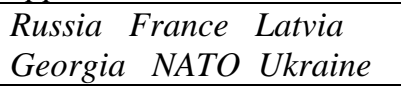 & $\begin{array}{l}\text { Georgia } \\
\text { Russia }\end{array}$ \\
\hline $\begin{array}{l}\text { Adjectives of } \\
\text { Nationality and other }\end{array}$ & $\begin{array}{ll}\text { Georgian } & \text { Russian } \\
\text { European } & \text { Independent }\end{array}$ & $\begin{array}{l}\text { Georgian Russian Soviet } \\
\text { Political }\end{array}$ \\
\hline Mental Process & Mean think & \\
\hline Process & $\begin{array}{l}\text { Controlled Supporting/ed } \\
\text { Elected Occupying } \\
\text { Inscribed abducted }\end{array}$ & $\begin{array}{l}\text { Going Called Know } \\
\text { Residing }\end{array}$ \\
\hline $\begin{array}{l}\text { Abstract Issues and } \\
\text { Entities }\end{array}$ & $\begin{array}{l}\text { Candidature Exile } \\
\text { Initiatives Provocation } \\
\text { stability }\end{array}$ & $\begin{array}{l}\text { Facilitation Union Exile } \\
\text { Kremlin } \\
\text { Elections Georgian dream } \\
\text { citizenship }\end{array}$ \\
\hline $\begin{array}{l}\text { Concrete Issues and } \\
\text { Entities }\end{array}$ & $\begin{array}{l}\text { Constitution Diplomat } \\
\text { Line Territory population }\end{array}$ & $\begin{array}{l}\text { TV Chicken Mistake } \\
\text { Passport country }\end{array}$ \\
\hline Words of Apology & & pardon \\
\hline Other & Very & Absolutely Frankly Very \\
\hline
\end{tabular}

The research identified the following conceptual metaphor source domains: War, Sport, Journey, Theatre, Builder and 21 types of metaphorically used lexemes at the text/discourse level. Table 2. represents frequencies of metaphorically used lemmas in relation to conceptual 
metaphors and politicians. The most prominent source domains are Journey, Sport and War. Abbreviations SZ and GV stand for Salome Zurabishvili and Grigol Vashadze respectively.

Table 2. Frequencies of Metaphorically used lemmas

\begin{tabular}{|c|c|c|c|c|c|c|c|c|c|c|}
\hline & \multicolumn{2}{|c|}{ WAR } & \multicolumn{2}{|c|}{ SPORT } & \multicolumn{2}{|c|}{ JOURNEY } & \multicolumn{2}{|c|}{ THEATRE } & \multicolumn{2}{|c|}{ BUILDER } \\
\cline { 2 - 11 } & SZ & GV & SZ & GV & SZ & GV & SZ & GV & SZ & GV \\
\hline $\begin{array}{c}\text { Metaphoric } \\
\text { Types }\end{array}$ & 6 & 2 & 2 & 4 & 4 & 1 & 2 & 3 & 1 & 1 \\
\hline $\begin{array}{c}\text { Metaphoric } \\
\text { tokens }\end{array}$ & 18 & 6 & 3 & 15 & 27 & 2 & 4 & 4 & 3 & 1 \\
\hline $\begin{array}{c}\text { mTTR - } \\
\text { metaphoric } \\
\text { Type/Token } \\
\text { ratio }\end{array}$ & $\mathbf{0 . 3 3}$ & $\mathbf{0 . 3 3}$ & $\mathbf{0 . 6 7} \mathbf{0 . 2 7}$ & $\mathbf{0 . 1 5}$ & $\mathbf{0 . 5}$ & $\mathbf{0 . 5}$ & $\mathbf{0 . 7 5}$ & $\mathbf{0 . 3 3}$ & $\mathbf{1}$ \\
\hline $\begin{array}{c}\text { Metaphoric } \\
\text { density/1000 } \\
\text { words }\end{array}$ & $\mathbf{3 . 6}$ & $\mathbf{2 . 3 7}$ & $\mathbf{0 . 6}$ & $\mathbf{5 . 9}$ & $\mathbf{5 . 4}$ & $\mathbf{0 . 7 9}$ & $\mathbf{0 . 8}$ & $\mathbf{1 . 6}$ & $\mathbf{0 . 6}$ & $\mathbf{0 . 3 9}$ \\
\hline
\end{tabular}

\section{The 'Journey' source domain}

The metaphor 'Politics is Journey' goes back to Lakoff and Johnson's (1999) general conceptual metaphor 'Purposes are Destinations' which functions on the scheme Source-Path-Goal (Johnson, 1987). Taking this model into consideration, we can say that if a discourse participant is heading towards a destination, no matter what challenges and obstacles he/she may have - 'Purposeful Activity is Moving on a Path towards a Destination' (Lakoff, 1993). If we consider the fact that destinations are regarded positive, since a person is striving to reach them, then this journey metaphor positively evaluates certain political aspects /policies (Charteris-Black, 2004, p.93). The journey metaphor embodies the goal-oriented movement which makes it fairly productive in the political discourse (Charteris Black, 2005; Musolff, 2004; Semino, 2002). In the present case study, the journey metaphor used in two Presidential candidates' interviews is investigated, which is realized at the text level by the following lexemes: step, towards, way, move.

The concordance shows that majority of the token types which are used metaphorically in Salome Zurabishvili's interviews is connected with the metaphoric expression move combined with keywords such as European Union, Nato, Georgia, American Partners, Territory, occupying and comparative adjectives - closer, faster - to intensify the movement towards the destination along with the personal pronouns /keywords 'I' and 'we' (examples 1-7).

1) “... and given my experience and past and contacts, I intend to be a very active one that advocates Georgia moving closer and into the European Union." 
2) "So, it's something that is becoming very concrete for the Georgian population, but this election was the declaration by the Georgian population that it wants to move faster, closer to the European Union and so, we have the best chance and I intend to deliver."

3) "We need to work a lot, we need a lot of new ideas, to discuss them with Americans as well as Europeans and where it is where we can move."

4) "I think that I am very well suited to accompany this last transition of Georgia towards the European Union and NATO and its western destiny."

5) "I don't think that at this time and age Russia is behaving the way it does on our occupying line where every day, we have people that are abducted. This line is moving, it's a constant threat that it is moving inside our territory, very close to Tbilisi or the way Russia is behaving today with Ukraine. I don't think that we can today enter cooperation mode. I don't think there is any balance. We are Europe and Europeans. If the West and Europe and our American Partners move to any form of discussion with Russia, that's where we need to be close, informed in order for our principles, our objectives, our sovereignty and territorial integrity to be respected and supported and supported beyond the table as such. That's the way to go."

6) "We have to try to figure out with our partners what would be the new ways for Georgia to move from this rather stagnant situation where we cannot do anything with these occupied territories to a new stage."

7) "If the West and Europe and our American Partners move to any form of discussion with Russia, that's where we need to be close, informed in order for our principles, our objectives, our sovereignty and territorial integrity to be respected and supported and supported beyond the table as such."

The source domain of 'Journey' is certainly mapped on the domain of politics which may be associated either with masculinity or femininity depending on the agency - whether the linguistic metaphor comes across as active or passive, which means that this metaphor is multi-faceted and related to personal experiences and political scenarios. The 'Journey' metaphors which were identified in Salome Zurabishvili's interviews tend to display more active agency (examples 1-7) along with the excessive use of keyword personal pronoun 'I' which make her an active, powerful candidate. The female politician uses sport and war metaphors alongside. It might be connected with the social and political environment which supports identity construal. Therefore, the journey metaphor is not as masculine as sport 
metaphor, but the active linguistic structures used alongside is an attempt to promote female agency and power.

\section{The 'Sport' source domain}

The 'Sport' metaphors are widely used in political discourse (Balbus, 1975, p.26) indicating the existence of opposing sides in the political arena which obey certain rules of conduct (Howe 1988:89) in order to play and win respectively. Therefore, the elements of sport are quite compatible with politics and it is obvious that the source domain of 'Sport' is easily mapped onto the target domain of 'Politics'. Gibbs (1994, p.140) highlights that "many of the metaphors used in politics draw heavily and systematically on the languages of sport and warfare". The pervasive use of metaphors in the political discourse is supposed to be conditioned by the most significant function of this linguistic tool - the function of influencing/persuading the audience. Additionally, Kovecses (2010, p.41) posits that "games and sport are characterized by certain properties that are commonly used for metaphorical purposes". Moreover, "the competitive nature of both elections and professional sport seems a sufficient basis for frequent metaphorization of elections through sport" (Fetzer and Lauerbach, 2007, p.87). There is the aspect that is worth focusing on that 'in contrast to 'War' metaphors, 'Sport' metaphors suggest fair play and the chance for "peaceful resolution" (Howe, 1988 , p.95). The pervasiveness of sport metaphor might be explained by the fact that "competitive sports metaphors place positive associations on winning and value the attributes that make winning more likely" (Charteris-black, 2013, p.188).

The evidence for the 'Sport' source domain was found in both politicians' discourse. Here is the list of metaphoric expressions/lemmas at the text level which realize the above-mentioned conceptual metaphor 'Politics is Sport': play, compete, lose, win/won, round, participate. These metaphoric expressions are more evident in Grigol Vashadze's interviews with more emphasis on lexemes win, round and participate in combination with the keywords examples 8-10).

8) "Do you know, this is the official version of the so-called government and the so-called Georgian Dream, in reality, won the first round."

9) "So, I was a Soviet Diplomat and I can tell you that I am very proud of it because I have participated_in negotiations which made our life safer."

10) "Everybody understands that when we are winning not if we are winning those elections, we are winning the referendum on our country, and we are bringing closer snap parliamentary elections". 
The use of sport metaphor makes the male candidate come across as more competitive and reinforces traditional attitudes.

\section{The 'War' source domain}

The 'War' metaphor is the most significant one as it highlights the nature of agency. Moreover, it is equally manifested in the political speeches of the candidates. The use of ' War' domain is inherently associated with masculinity and competitiveness. The female representative is as ready to fight as the male one. And the examples given below are supposed to be the proof:

11) Russia is projecting power on our territory and we have to be fighting and trying to preserve its independence.

12) We need to confront our positions, to confront it with our partners.

13) I am not interested in the political battle and I intend to be such a president who will try to bring, to be above the political parties that will not descend into the political battles.

Grigol Vashadze uses war metaphor as well:

14) So-called Georgian Dream is very right when they are fighting the deadly fight for these polls. But they have already lost their fight.

15) I spent five years of my life fighting with Russia and I succeeded and left Russia in a shameful company of Venezuela, Syria, Nicaragua...

16) Yes. You know, it is a strange question because, quite frankly, I have never been choosing my friends according to their political beliefs; yes, he is my friend and if there is a confrontation between my beliefs and his beliefs, I will try my best to retain our friendship.

Nonetheless, Salome Zurabishvili's War metaphor is associated with fighting against occupant Russia, while Grigol vashadze focuses more on a fight as a presidential candidate.

\section{Conclusion}

'Politics is Sport', 'Politics is Journey' and 'Politics is War' define a cognitive aspect of the politicians' discourses. The 'War' metaphor is almost equally evident in both candidates' discourse, which shows that they are ready to fight and win. But the 'Sport' source domain ascribes more competitiveness to the male politician's speech whereas the 'Journey' source domain attributes more tranquil and destination-oriented attitude to a female politician's agency. Still, Journey metaphor is a different case. As we can see the ideology of "different voice" pales here and women might also adopt the masculine way of discourse making. Nonetheless, the use of journey metaphor makes the female candidate appear less competitive or bound by struggle. Still, a lot has to be done in terms of a cognitive shift to cause equal discursive positions for male and female politicians. 
Within the premises of the research far-reaching claims based on the selected mini corpora could not be drawn. However, whatever has been found is significant for the Georgian political discourse in terms of revealing politicians' capability of performing gender, which makes them appear more or less masculine/feminine. And the latter changes in line with the social and political context or expectations imposed by particular societal norms.

\section{References:}

1. Anthony, L. (2020). AntConc (Version 3.5.9) [Computer Software]. Tokyo, Japan: Waseda University. Available from https://www.laurenceanthony.net/software

2. Balbus, I. D. (1975). Politics as Sport: The Political Ascendancy of the Sports. Metaphor in America 26 (10): 26-39.

3. Baxter, J. (2012). Women of the Corporation: A sociolinguistic perspective of senior women's leadership language in the UK. Journal of Sociolinguistics, 16(1), 81-107.

4. Butler, J. (1990). Gender Trouble: Feminism and the Subversion of Identity. London: Routledge.

5. Cameron, D. (2007). The Myth of Venus and Mars: Do Men and Women Really Speak Different Languages? Oxford: Oxford University Press.

6. Cameron, D., and S. Shaw. (2016). Gender, Power and Political Speech. Women and Language in 2015 General Election. London: Palgrave MacMillan

7. Charteris-Black, J. (2004). Corpus Approaches to Critical Metaphor Analysis. Basingstoke: Palgrave Macmillan.

8. Charteris-Black, J. (2005) Politicians and Rhetoric: the Persuasive Power of Metaphor. Basingstoke: Palgrave Macmillan.

9. Charteris-Black, J. (2013). Analysing Political speeches: Rhetoric, Discourse and Metaphor. New York: Palgrave Macmillan.

10. Connell, R. (1995). Masculinities. Berkeley: University of California Press.

11. Connell, R., and J.W. Messerschmidt. (2005). Hegemonic Masculinity: Rethinking the Concept. Gender \& Society, 19(6): 82959.

12. Fairclough, N. (2003). Analysing Discourse: Textual Analysis for Social Research. London: Routledge.

13. Fetzer, A., \& G. Lauerbach. (2007). Political Discourse in the Media: Cross- cultural Perspectives. Amsterdam: John Benjamins Publishing Co.

14. Fiksdal, S. (1999). Metaphorically Speaking: Gender and Person. Language Sciences, 21(3): 345-54. 
15. Gibbs, R., Jr. (1994). The Poetics of Mind: Figurative Thought, Language, and Understanding. Santa Cruz: Cambridge University Press.

16. Howe, N. (1988). Metaphor in Contemporary American Political Discourse 3 (2): 87-104.

17. Halliday, M., and C. Matthiessen. (2004) Introduction to Functional Grammar, 3rd ed. London: Arnold.

18. Hegstrom, J., L. and J. McCarl-Nielsen. (2002). Gender and Metaphor: Descriptions of Familiar Persons. Discourse Processes, 33(3): 21934.

19. Hines, C. (1999). Rebaking the Pie: the WOMAN AS DESSERT Metaphor. In M. Bucholtz, A.C. Liang and L. Sutton (eds) Reinventing Identities: the Gendered Self in Discourse. Oxford: Oxford University Press.

20. Holmes, J. (1998). The question of sociolinguistic universals. In J. Cotes (Ed.), Language and gender: a Reader (pp. 461-483). Oxford: Blackwell.

21. Holmes , J., \& Meyerhoff, M. (1999). The community of practice: Theories and methodologies in language and gender research. Language in Society, 28(2), 173-183. Retrieved from .www.jstor.org/stable/4168923 doi: Crossref.

22. Liu, B. (2015). Sentiment analysis: Mining opinions, sentiments, and emotions. Cambridge: Cambridge University Press. Crossref.

23. Johnson, M. (1987). The Body in the Mind: the Bodily Basis of Meaning, Imagination, and Reason. Chicago: University of Chicago Press.

24. Kanter, R, M. (1993). Men and Women of the Corporation ( $2^{\text {nd }}$ ed.). New York: Basic Books.

25. Kövecses, Z. (2005). Metaphor in Culture: Universality and Variation. Cambridge: Cambridge University Press.

26. Kövecses, Z. (2010). Metaphor: a practical introduction. New York: Oxford University Press.

27. Koller, V. (2003). Metaphor Clusters, Metaphor Chains: Analyzing the Multifunctionality of Metaphor in Text. Metaphorik.de, 5: 115-34, http://www.metaphorik.de/05/koller.pdf

28. Koller, V. (2004a). Businesswomen and War Metaphors: "Possessive, Jealous and Pugnacious"'? Journal of Sociolinguistics, 8(1): 3-22.

29. Koller, V. (2004b). Metaphor and Gender in Business Media Discourse: a Critical Cognitive Study. Basingstoke: Palgrave Macmillan.

30. Koller, V., and E. Semino. (2009). Metaphor, Politics and Gender: A Case Study from Germany. Politics, Gender and Conceptual 
Metaphors. K. Ahrens (Ed). (pp. 9-35). New-York: Palgrave Macmillan

31. Lakoff, G. (1993). The Contemporary Theory of Metaphor. A. Ortony (Ed.) Metaphor and Thought, 2nd edn. Cambridge: Cambridge University Press.

32. Lakoff, G., and M. Johnson. (1980). Metaphors We Live By. Chicago: University of Chicago Press.

33. Lakoff, G., and M. Johnson. (1999). Philosophy in the Flesh: the Embodied Mind and Its Challenge to Western Thought. New York: Basic Books.

34. Luchjenbroers, J. (1998). Animals, Embryos, Thinkers and Doers: Metaphor and Gender Representation in Hong Kong English. Australian Review of Applied Linguistics, 21(2): 105-22.

35. Meyerhoff, M. (2015). Gender Performativity'. The International Encyclopedia of Human Sexuality (Whelehan, P and A, Bolin eds). $1^{\text {st }}$ ed. John Wiley \& Sons, DOI: 10.1002/9781118896877.wbiehs 178

36. Musolff, A. (2004). Metaphor and Political Discourse: Analogical Reasoning in Debates about Europe. Basingstoke: Palgrave Macmillan.

37. Pragglejaz Group. (2007). MIP: a Method for Identifying Metaphorically Used Words in Discourse. Metaphor and Symbol, 22(1): 1-39.

38. Velasco, S. (2005). A Critical Cognitive-Pragmatic Approach to Advertising Gender Metaphors. Intercultural Pragmatics, 2(3): 219 52.

39. Semino, E. (2002). A Sturdy Baby or a Derailing Train? Metaphorical Representations of the Euro in British and Italian Newspapers. Text, 22(1): 107-39.

40. Shaw, S. (2005). Governed by the Rules? The Female Voice in Parliamentary Debates. J. Baxter (Ed.) Speaking Out: the Female Voice in Public Contexts. Basingstoke: Palgrave Macmillan.

41. Shaw, S. (2020). Gender and Political Speech. The International Encyclopedia of Gender, Media and Communication. https://doi.org/10.1002/9781119429128.iegmc210

42. Tannen, D. (1991). You Just Don't Understand: Women and Men in Conversation. New York: Ballantine Books

43. Wilson, F. (1992). Language, Technology, Gender, and Power. Human Relations, 45(9): 883-904.

44. Wodak, R. (2001). What is CDA about: A summary of its history, important concepts and its developments. R. Wodak and M. Meyer (Eds.) Methods of Critical Discourse Analysis. (pp.1-13) London: Sage 


\section{Appendix}

\section{Salome Zurabishvili corpus - 4988 words}

SZ 1

https://www.youtube.com/watch?v=z3audjCs82M

DW News. Published on Nov.9, 2018. Zhanna Nemtsova's interview with Salome Zurabishvili.

\section{SZ 2}

https://video.i24news.tv/details/_5973225792001?lang=en\&utm_medium=n av_bar_button\&utm_source=en_website i24news.

\section{THE RUNDOWN | Salome Zurabishvili discusses historic victory |} Thursday, November 29th 2018

SZ 3

https://www.euronews.com/2018/11/29/euronews-speaks-exclusively-togeorgia-s-new-president-elect-salome-zurabishvili

Euronews speaks to Georgia's new President-elect, Salome Zurabishvili By Katy Dartford • last updated: 29/11/2018

\section{SZ 4}

https://www.businessinsider.com/r-georgian-president-elect-takes-strongline-towards-moscow-after-contentious-vote-2018-12

Georgian president-elect takes strong line towards Moscow after contentious vote

Reuters

Dec. 1, 2018,

\section{SZ 5}

https://www.youtube.com/watch?v=Jih0BtC6TJQ

BBC news

Published on Nov. 29, 2018 


\section{Grigol Vashadze Corpus 2533}

\section{GV 1}

https://www.dw.com/en/georgian-candidate-grigol-vashadze-denies-tightrussia-ties/a-46197576

https://www.dw.com/en/georgian-candidate-grigol-vashadze-denies-tightrussia-ties/a-46197576

Georgia's presidential candidate: I've spent five years fighting with Russia | DW English

https://www.youtube.com/watch?v=mF8GXDC2M18

GV2

AP Archive

'Protest against results of presidential election in Georgia'

http://www.aparchive.com/search?startd=\&endd=\&allFilters=\&query=Prote

st+against+results+of+presidental+election+in+Georgia\&advsearchStartDate Filter=\&advsearchEndDateFilter=\&searchFilterHdSDFormat=All\&searchFil terDigitized=All\&searchFiltercolorFormat=All\&searchFilteraspectratioForm at $=$ All

\section{GV 3}

RadioFreeEurope RadioLiberty

Georgians Vote in Tight Presidential Election

https://www.rferl.org/a/georgia-presidential-elections-voting/29626196.html

GV 4

AP Archive

GEORGIA EXIT POLL

http://www.aparchive.com/metadata/youtube/c002365a492c112e780432750

b2af46a

\section{GV 5}

AP Archive

Opposition members protest inauguration of president http://www.aparchive.com/metadata/youtube/bb549344811df01d19ce717e3b d16a70 